\title{
Extractive Visible Spectrophotometric Determination of Lamotrigine in Pure and Pharmaceutical Formulations
}

\author{
N. V. V. NAGA MALLESWARA RAO, S. PULLA REDDY, \\ S. V. M. VARDHAN and C. RAMBABU* \\ Department of Chemistry, Acharya Nagarjuna University, Guntur, A.P, India \\ rbchintala@gmail.com
}

Received 23 October 2012 / Accepted 12 November 2012

\begin{abstract}
Two simple, sensitive, accurate and economical spectrophotometric methods (A \& B) for the determination of lamotrigine (LMT) in pure and pharmaceutical formulations (tablets) are described in the present work. Method A is based on the formation of coloured ion-association complex between lamotrigine and tropaeolineo-oo (TPooo) with absorption maximum at $485 \mathrm{~nm}$ and obeys Beer's law in the concentration range of $5-25 \mu \mathrm{g} / \mathrm{mL}$. Formation of ion-association complex between lamotrigine and alizarine Red S (ARS) to yield a coloured chromogen exhibiting absorption maximum at $440 \mathrm{~nm}$ (Method B) obeying Beer's law in the concentration range of $5-25 \mu \mathrm{g} / \mathrm{mL}$ forms the basis of Method B. The two methods have been validated statistically through recovery studies. The results are compared with those obtained using UV spectrophotometric method (Reference method) in chloroform at $260 \mathrm{~nm}$.
\end{abstract}

Keywords: Lamotrigine (LMT), Tropaeolineo-oo (TPooo), Alizarine Red S (ARS)

\section{Introduction}

Lamotrigine (LMT), chemically known as [3,5-diamino-6-(2,3-dichlorophenyl)-1,2,4-triazine], is a phenyltriazine derivative (Figure 1) used to treat children with severe epilepsy ${ }^{1-3}$. Several analytical methods have been reported for the determination of LMT in pharmaceuticals or in biological fluids including reverse-phase HPLC ${ }^{4-11}, \mathrm{GC}$ with nitrogen phosphorous detector ${ }^{12}$, capillary electrophoresis ${ }^{13-14}$, adsorptive stripping voltammetry ${ }^{15,16}$ and spectrophotometry ${ }^{17-21}$.<smiles>Nc1nnc(-c2cccc(Cl)c2Cl)c(N)n1</smiles>

Figure 1. Structure of lamotrigine

The aim of the present work was to develop simple, accurate, precise and inexpensive visible spectrphotomertic methods for the determination of lamotrigine in pure and pharmaceutical formulations. 


\section{Experimental}

All spectral measurements were done using an Elico, UV - Visible spectrophotometer (SL159) with $1.0 \mathrm{~cm}$ matched quartz cells.

\section{Reagents}

All the chemicals used were of analytical reagent grade and used as received. Double distilled water was used in the preparation of all solutions. All the solutions were prepared afresh daily.

\section{Method A}

\section{TPooo solution (Fluka; 0.2\%)}

This solution was prepared by dissolving $200 \mathrm{mg}$ of tropaeoline ooo in $100 \mathrm{~mL}$ of distilled water.

$\mathrm{HCl}$ (E. Merck, 0.1M)

This solution was prepared by diluting $8.6 \mathrm{~mL}$ of concentrated hydrochloric acid to $1000 \mathrm{~mL}$ with distilled water and standardized.

\section{Chloroform(Qualigens)}

AR grade of chloroform was used

\section{Method B}

ARS solution (Fluka;0.2\%)

Prepared by dissolving $200 \mathrm{mg}$ of ARS dissolved in $100 \mathrm{~mL}$ distilled water.

\section{$\mathrm{HCl}$ (E. Merck, $0.1 \mathrm{M})$}

Prepared by diluting $8.6 \mathrm{~mL}$ of concentrated hydrochloric acid to $1000 \mathrm{~mL}$ with distilled water and standardized.

\section{Chloroform(Qualigens)}

AR grade of chloroform was used

\section{Preparation of standard drug solutions}

$100 \mathrm{mg}$ of lamotrigine (Hetero Drugs Limit, Hyderabad, India as a gift sample) was weighed accurately and transferred into a separate $100 \mathrm{~mL}$ volumetric flask and dissolved in $10 \mathrm{~mL}$ ethanol. To this, distilled water was added up to the mark to get the stock solution concentration of $1.0 \mathrm{mg} / \mathrm{mL}$ and this stock solution was diluted step wise with distilled water to get the working standard solutions of concentration of $100 \mu \mathrm{g} / \mathrm{mL}$ for method A and B.

\section{Preparation of tablets formulations}

Twenty tablets were weighed accurately and ground into a fine powder. An amount of powder containing $10 \mathrm{mg}$ of LMT was accurately weighed and transferred into a $100 \mathrm{~mL}$ calibrated flask and $10 \mathrm{~mL}$ ethanol was added. The content was shaken for about $30 \mathrm{~min}$; the volume was diluted to the mark with water and mixed well and filtered using a Whatman no.41 filter paper. The filtrate containing LMT at a concentration $100 \mu \mathrm{g} / \mathrm{mL}$ was subjected to analysis by the procedure described above. 


\section{Proposed procedures}

\section{Method A \& B}

Into a series of $100 \mathrm{~mL}$ separating funnels, aliquots of standard lamotrigine solution of $0.5-2.5 \mathrm{~mL}$ containing $100 \mu \mathrm{g} / \mathrm{mL}$ for the methods A \& B, $6.0 \mathrm{~mL}, 0.1 \mathrm{M} \mathrm{HCl}$ and $2.0 \mathrm{~mL}$ of $2 \%$ dye solution ((TPooo) for method A and (ARS) for method B) were added successively and the total volume of aqueous phase in each separating funnel was made to $15.0 \mathrm{~mL}$ with distilled water. To each separating funnel $10 \mathrm{~mL}$ of chloroform was added and the contents were shaken for $2 \mathrm{~min}$. The two phases were allowed to separate and the absorbance of the separated chloroform layer was measured at $\lambda_{\max } 485 \mathrm{~nm}$ with TPooo, $440 \mathrm{~nm}$ for ARS against reagent chloroform blank.

\section{Results and Discussion}

In method A, the positively charged aliphatic primary nitrogen of lamotrigine molecule in acid medium was expected to attract the negatively charged part of the acidic dye TPooo and form an ion pair held together through electrostatic attraction forming orange red colored exhibiting absorption maximum $\lambda_{\max }$ at $485 \mathrm{~nm}$. In method $\mathrm{B}$ the same ion-association reaction was obtained for lamotrigine with ARS dye forming a yellow coloured ion association complex which exhibited absorption $\lambda_{\max }$ at $440 \mathrm{~nm}$ (Scheme 1)

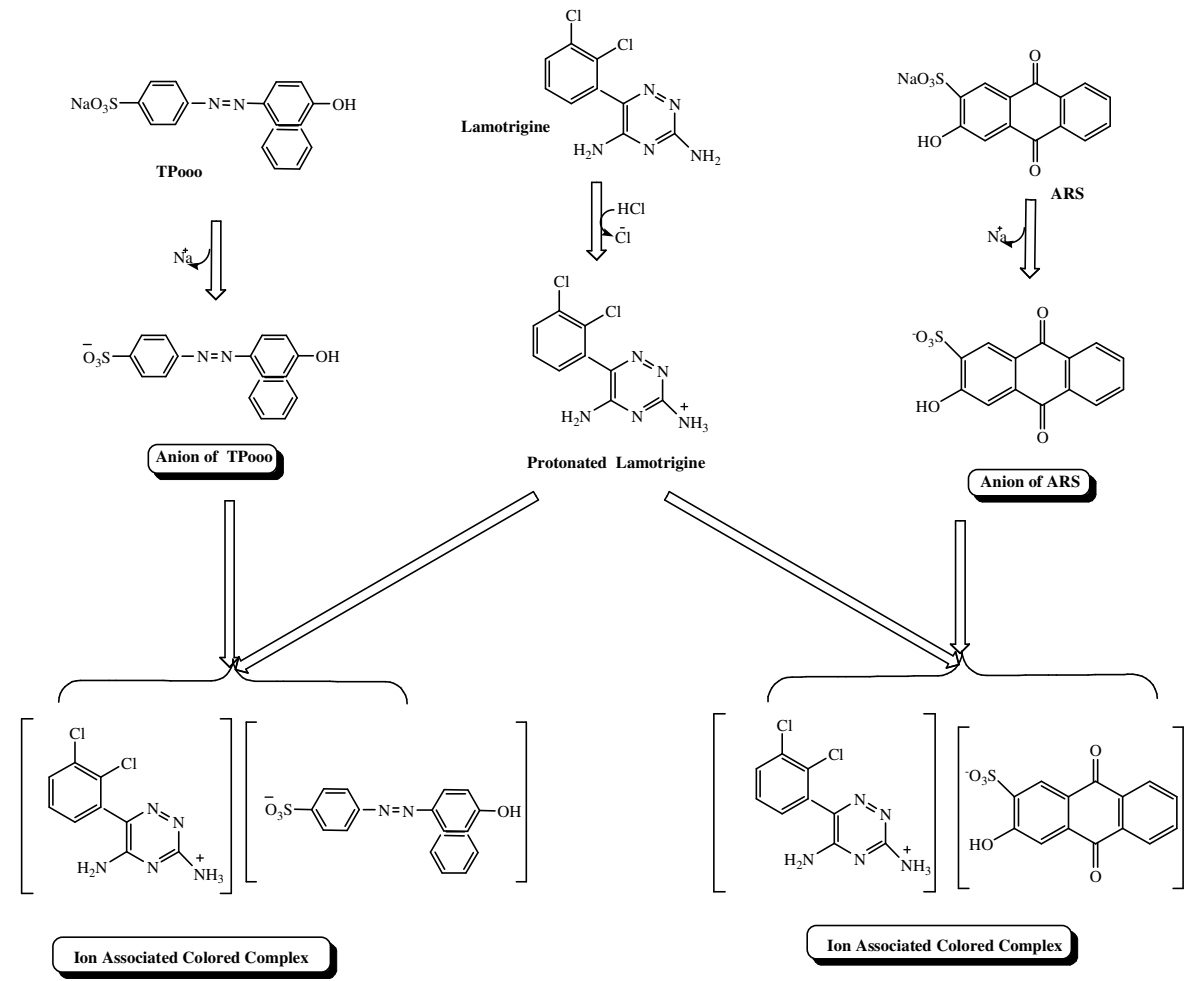

\section{Scheme 1}

The reaction conditions for the proposed methods were established by variation of one parameter at a time. For both the methods (A \& B), use of 0.5-2.5 mL of drug solution, $2 \mathrm{~mL}$ of dye solution and $10 \mathrm{~mL}$ chloroform solvent were considered optimal. 
The optical characteristics such as absorption maxima, Beer's law limits, molar absorptivity and Sandell's sensitivity are presented in Table.1. The regression analysis using the method of linear least squares was made for the slope (b), intercept (a) and correlation (r) obtained from different concentrations and the results are summarized in Table 1. The limits of detection (LOD) and quantification (LOQ) calculated according to ICH guidelines are also presented in Table 1. The present relative Standard deviation and percent range of error (\%RSD) calculated from the six measurements $3 / 4$ of the upper Beer's law limits of lamotrigine are given in Table 1. These results showed that the proposed methods have reasonable precision. Comparison of the results obtained with the proposed and UV methods for dosage forms (Table.2) confirm the suitability of these methods for pharmaceutical dosage forms. The results of recovery experiments analyzed by the proposed methods are summarized in Table.2. The other active in gradients and excipients usually present in pharmaceutical dosage forms did not interfere.

Table 1. Optical and regression characteristics, precision and accuracy of the proposed methods for LMT

\begin{tabular}{|c|c|c|}
\hline Parameter & Method A & Method B \\
\hline$\lambda_{\max }, \mathrm{nm}$ & 485 & 440 \\
\hline Beer's law limits, $\mu \mathrm{g} / \mathrm{mL}$ & $5-25$ & $5-25$ \\
\hline Molar absorptivity, $1 \mathrm{~mol}^{-1} \cdot \mathrm{cm}^{-1}$ & $4.126 \times 10^{3}$ & $3.412 \times 10^{3}$ \\
\hline Sandell's sensitivity ( $\mu \mathrm{g} . \mathrm{cm}^{-2} / 0.001$ absorbance unit) & 0.08554 & 0.2994 \\
\hline Optimum photometric range, $\mu \mathrm{g} / \mathrm{mL}$ & $5-20$ & $5-20$ \\
\hline \multicolumn{3}{|l|}{ Regression equation $(\mathrm{Y}=\mathrm{a}+\mathrm{bc})$} \\
\hline slope (b) & 0.04053 & 0.01088 \\
\hline Standard deviation on slope $\left(\mathrm{S}_{\mathrm{b}}\right)$ & $2.070 \times 10^{-2}$ & $4.586 \times 10^{-3}$ \\
\hline Intercept (a) & $2.499 \times 10^{-4}$ & $4.999 \times 10^{-3}$ \\
\hline Standard deviation on intercept $\left(\mathrm{S}_{\mathrm{a}}\right)$ & $1.373 \times 10^{-2}$ & $1.5211 \times 10^{-2}$ \\
\hline Standard error on estimation $\left(\mathrm{S}_{\mathrm{e}}\right)$ & $1.309 \times 10^{-2}$ & $1.450 \times 10^{-2}$ \\
\hline Correlation coefficient $(r)$ & 0.9998 & 0.9997 \\
\hline Relative standard deviation, $\% *$ & 1.226 & 1.6015 \\
\hline \multicolumn{3}{|l|}{$\%$ Range of error (confidence limits) } \\
\hline 0.05 level & 1.410 & 1.841 \\
\hline 0.01 level & 2.210 & 2.887 \\
\hline$\%$ error in Bulk samples ${ }^{* *}$ & 0.282 & -0.29 \\
\hline
\end{tabular}

"Average of six determinations considered. ${ }^{* *}$ Average of three determinations

Table 2. Estimation of lamotrigine in pharmaceutical formulations

\begin{tabular}{|c|c|c|c|c|c|c|}
\hline \multirow{3}{*}{ Sample } & \multirow{3}{*}{$\begin{array}{l}\text { Labelled } \\
\text { amount, mg }\end{array}$} & & \multirow{3}{*}{$\begin{array}{l}\text { UV } \\
\text { method }\end{array}$} & \multicolumn{2}{|c|}{$\begin{array}{c}\text { \%Recovery of } \\
\text { Proposed methods }\end{array}$} \\
\hline & & Proposed & methods* & & \multirow{2}{*}{ Method A } & \multirow{2}{*}{ Method B } \\
\hline & & Method A & Method B & & & \\
\hline Tablet - 1 & 100 & 99.98 & 101.2 & 99.97 & 100.0 & 101.2 \\
\hline Tablet - 2 & 200 & 199.97 & 199.75 & 199.99 & 99.98 & 99.87 \\
\hline
\end{tabular}

*Average of six determinations. ** Mean and standard deviation of six determinations

\section{Conclusion}

The proposed methods are accurate, precise, simple, sensitive and rapid and can be applied successfully for the determination of lamotrigine in pure and its pharmaceutical formulations in a routine manner without interference and with good sensitivities. 


\section{Acknowledgement}

The authors on thankful to M/S Hetero Drugs Limit, Hyderabad for gift sample and Department of Chemistry, Acharya Nagarjuna University,Guntur, A.P, India for providing additional laboratory facilities.

\section{References}

1. Goa K L, Ross S R and Chrisp P, Drugs, 1993, 46, 152-176.

2. Messenheimer J , Mullens E L, Giorgi L and Young F, Drug Saf, 1998, 18, 281-296.

3. Pellock J M, J Child Neurol, 1997, 12, S48-S52.

4. Emami J, Ghassami N and Ahmadi F, J Pharm Biomed Anal, 2006, 40(4), 999-1005.

5. Saracino A M, Bugamelli F, Conti M, Amore M and Raggi M A, J Sep Sci., 2007, 30, 2249-2255.

6. Beck O, Ohman I and Nordgren H K, Ther Drug Monit., 2006, 28, 603-607.

7. Zufia L, Aldaz A, Ibanez N and Viteri C, J Pharm Biomed Anal, 2009, 49, 547-553.

8. $\quad$ Greiner C and Haen E, J Chromatogr B, 2007, 854(1-2), 338-344.

9. Greiner-Sosanko E, Giannoutsos S,Lower D R, Virji M A and Krasowski M D, $J$ Chromatogr Sci., 2007,45, 616-622.

10. Ching-Ling C, Chen-His C and Yoa-Pu Hu O, J Chromatogr B, 2005, 817, 199-206.

11. Bompadre S, Tagliabracci A, Battino M and Giorgetti R, J Chromatogr B, 2008, 863, 177-180.

12. Watelle M, Demedts P, Franck F, De Deyn P P, Wauters A and Neels H, Ther Drug Monit., 1997, 19, 460-464.

13. Zheng J, Jann M W, Hon Y Y and Shamsi Y S A, Electrophoresis, 2004, 25, 2033-2043.

14. Pucci V, Bugamelli F, Baccini C and Raggi M A, Electrophoresis, 2005, 26, 935-942.

15. Burgoa Calvo M E, Renedo O D and Arcos Martinez M J, Talanta, 2007, 74(1), 59-64.

16. Burgoa Calvo M E, Renedo O C and Arcos Martinez M J, Anal Chim Acta, 2005, 549, 74-80.

17. Youssef N F and Taha E A, Chem Pharm Bull., 2007, 55(4), 541-545.

18. Talekar R S, Dhake AS, Sonaje D B and Mourya V K, Indian J Pharm Sci., 2000, 62, 51-52.

19. Rajendraprasad N, Basavaiah K and Vinay K B, Ecletica Quimica, 2010, 35(1), 55-66.

20. Rajendraprasad N, Basavaiah K and Vinay K B, Indian J Chem Tech., 2010, 17, 220-228.

21. Vinay K B, Revanasiddappa H D and Rajendra Prasad N, J Food Drug Anal., 2009, 17, 424-33. 